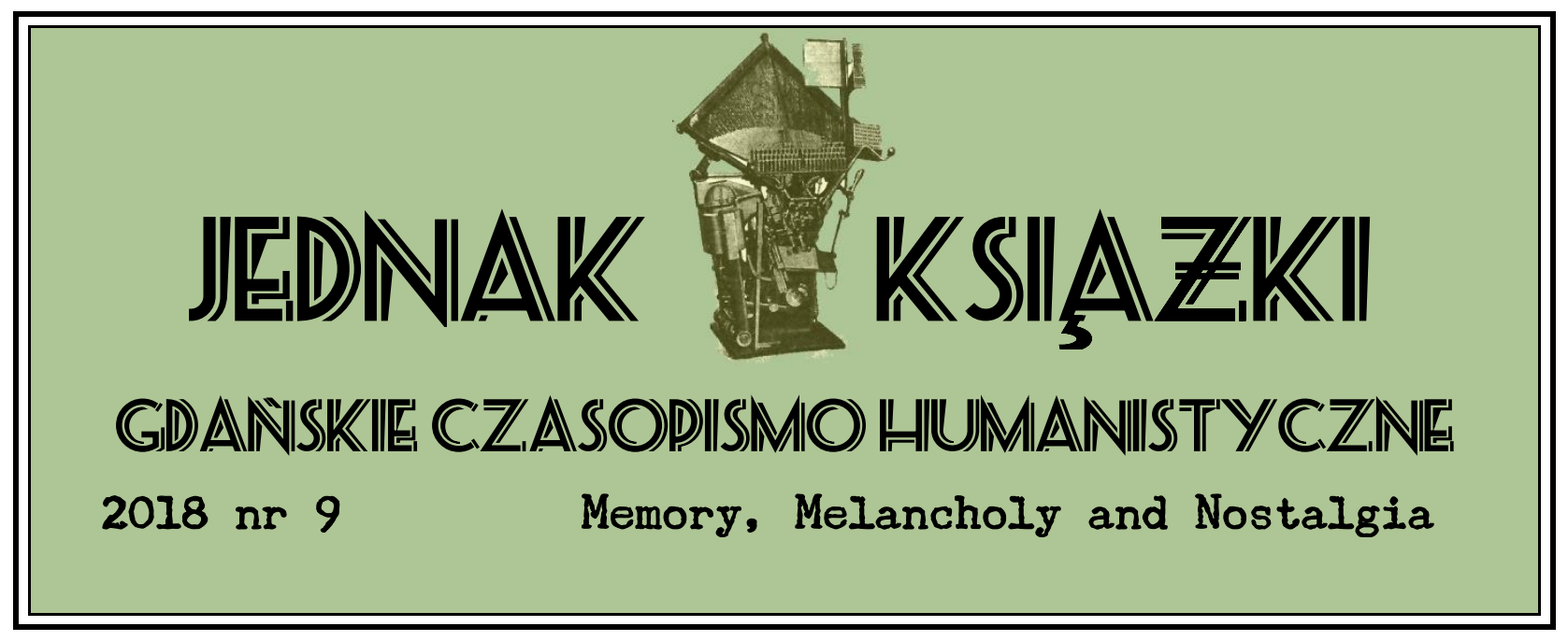

\title{
ESSAYS
}

https://doi.org/10.26881/jk.2018.9.15

\section{THE (PLAYFULLY) MELANCHOLIC STILL LIFE OF CONTEMPORARY PAINTING}

FRANCES WOODLEY

Aberystwyth University (Wales, United Kingdom)

School of Art

"That the affection is corporeal, i.e. that recollection is a searching for an 'image' in a corporeal substrate, is proved by the fact that in some persons, when, despite the most strenuous application of thought, they have been unable to recollect, it (viz. the effort at recollection) excites a feeling of discomfort, which, even though they abandon the effort at recollection, persists in them none the less; and especially in persons of melancholic temperament. For these are the most powerfully moved by presentations." (Aristotle 2001:453a: 15). 
his paper aims to throw light on contemporary painting of still life and the ways in which it exists in forms of dialogue with the ideas and objects implicit in its tradition.

L Tradition, a form of collective memory, exists because its forms are reiterated and transformed over time. As a living memory, tradition's objects exist in our present and are consequently open to interpretation for us in ways that are both different to the past and particular to our own time.

The first part of my paper considers contemporary painting of still life in relation to memory and tradition, loss and retrieval, melancholy and reverie. In particular, I explore how these themes and issues are creatively worked through using methods of appropriation, reiteration and playful imagining. I present these themes and issues in two stages: Firstly, Tradition's Address and secondly, Melancholy, Reverie and Play in the Contemporary Painting of Still Life.

The second part of my paper, by way of exemplifying the first, is an exploration of the ways in which memory, melancholy and play are put to work in paintings by three contemporary British painters: Emma Bennett, Alan Salisbury, and G.L. Brierley. Since 2013 I have had the privilege of working with these artists as part of a three year curatorial research project that has included the exhibitions: Still Life All Coherence Gone? (BayArt Gallery, Cardiff, 2014), and Still Life: Ambiguous Practices (Aberystwyth University, School of Art Gallery, 2015).

My research makes much use of the hermeneutical writing of Hans-Georg Gadamer, author of Truth and Method (2006) first published in German in 1960. Gadamer states that in addressing us, tradition invites a response, and that in responding to art of the past and to the tradition that it gives rise to, both are revived and transformed in the process. Memory, recall, reverie and imagination all play a part in the process of contemporary reimagining and transformation of the traditional genre of still life and this has led me to the phenomenological writings of Gaston Bachelard, in particular On Poetic Reverie and Imagination (2005), first published in French in 1960. Through memory, reverie, and play, the physical properties and technologies of painting and the changing sites of reception, the tradition of still life is able to live on. "The horizon is ... something into which we move and that moves with us. Horizons change for a person who is moving. Thus the horizon of the past, out of which all human life lives and which exists in the form of tradition, is always in motion." (Gadamer 2006: 303).

\section{Tradition's Address}

Still life painters before, and during, the seventeenth century used particular objects such as the hourglass, the half empty roemer, the unwinding lemon and the pocket-watch as symbols of 
passing time, transience and inevitable mortality. These objects were intended by painters and commissioners alike to be 'read' as the Latin memento mori (remember you will die) or vanitas derived from the Latin vanum (empty). They became distinct conventions within still life painting at that time. Alongside these still lifes were painted others depicting nature in artificial states -bouquets of flowers and fruits and vegetables in evocative states of ripeness, juiciness, dryness and decay, often synchronically and vertiginously arranged. With the raw were also depicted the cooked-the preserved, fermented, hung and baked_often represented as if caught in their penultimate prime as if reminding the overzealous collector or the hubristic citizen of the inescapable imminence of putrescence, collapse, and death.

Willem Claesz. Heda's Breakfast Table with Blackberry Pie (1631) with its restrained palette, its Eucharistic arrangement, its half eaten pie crust, its wound down pocket watch left carelessly open, its half-drunk glasses with others drained and tipped over, seems intended for its viewer as the melancholic reminder of the inevitable transience of life. (Vroom 1999). A message made all the more palatable by the visual and sensory reverie induced in the viewer brought on by the sheer brilliance of the painted reflections and textured foodstuffs. The artist's palette, his attentive precision to the entrapment of light, the ruin of the pie, and the implication of infinity in the background, are certainly melancholy inducing. Yet, this still life also sets up a push and pull between the melancholic inevitabilities of death and the drives of the living, those of desire and appetite. The modest melancholic reminders of man's frailties and death competed with the pronk stilleven (the sumptuous still life), of which Willem Kalf (1613-93) and Jan Davidsz. de Heem (1606-83) became important exponents. In comparison to the restrained symbolism and subtle indicators of status practiced by Willem Claesz. Heda (1594-1680) and Pieter Claesz (1597 -1660) in Haarlem, the pronk still life tumbled its stuff in precipitous heaps of excess that reflected new mercantile success. Painted for the rich and successful, these paintings lost their modest melancholic message for an unapologetically exuberant consumerist one, a form of double speak for 'remember you will die'.

Since the eighteenth century the painting of still life has generally been studio-based rather than a workshop practice. It has become an introverted affair, one of personal withdrawal from the world in order to imagine objects of the world into worlds of their own. Since Manet, still life painting has been obliged not just to represent but also to reflect on the ways in which it sets out to conform to, refer, allude, copy, parody or otherwise be in conversation with, its own tradition. It is this reflective conversation with past art that has become the readable and intertextual element in recent still life painting, rather than the melancholic symbolism of before. Yet, it too often bears this melancholic quality as can be seen in the paintings I discuss in Part II. 
In 2008 Glenn Brown appropriated Gustave Courbet's Red Apples at the Foot of a Tree (1871 -2) and mixed it up with the palette and style of Edwin Landseer's Twa Dogs (1822) in his still life painting, Burlesque (2008). Just a year before Vase of Flowers by a Window (1650-57) by Balthasar van der Ast had been appropriated by Ged Quinn in No-one Knows Who You Are (2006). So 'thieving' can also lead to play, that is, the intentional misremembering and misrepresentation of tradition.

Contemporary painting of still life thus walks a tightrope between tradition and contemporary practice to extend, interpret, reimagine, and transform itself. Memory in the Aristotlean sense is, according to Ricoeur: “... directly characterized as affection (pathos), which distinguishes it precisely from recollection. ... It is the contrast with the future of conjecture and expectation and with the present of sensation (or perception) that imposes this major characterization" (Ricouer 2004: 15). At its most dynamic, contemporary painting of still life breaks with tradition's constraints whilst simultaneously acknowledging them. In so doing, artists have an eye on the potential such traditional paintings offer for future painting.

\section{Melancholy, Reverie, and Play in Still Life Painting}

If contemporary still life is always in conversation with a memory of itself, the sense of loss that accompanies all memory must likewise be accompanied by a state of melancholy. I suggest, as many others have done, that melancholy is a common attribute of all still life painting.

Time has brought about forgetting and misunderstanding of still life's symbolic language and in so doing has made the language of its original messages largely unavailable to us. Instead, what remains interpretable is analysed by those holders of collective memory such as art historians, iconographers, and connoisseurs for example. Most seventeenth century viewers would have seen themselves as being part of a greater scheme of God's geocentric creation, and would have understood still life's invocations against earthly excesses in those terms. Though this symbolic language is generally no longer used, Mat Collishaw's recent series of C-Type photographs Last Meal on Death Row (2011) makes use of it through pastiche of a Dutch sub -genre of still life known as the modest onbeitje (breakfast piece) such as those mentioned earlier by Pieter Claesz. Collishaw has appropriated from the tradition's melancholic formal and symbolic conventions to make an equally melancholic, but also highly personal, image in photography.

Ever since the eighteenth-century romantic notion of the melancholic painter, it seems that painters of still life have been particularly prone to melancholic qualities in their painting brought 
on by the passing of time experienced as the reverie inducing, slow changes of light during the course of a day.

Ricoeur seems to conflate states of reverie and melancholy: “... is it not the sadness of meditative memory, the specific "mood" of finitude rendered conscious of itself? This sadness without a cause ..." (Ricoeur 2004: 76). In unhitching melancholia from mourning and madness Ricoeur frees himself to consider the power of the arts to bring "gaiety, humour, hope, trust, and also ... work", to bring with it "a dialectical humour in which Delight responds to Melancholia under the auspices of beauty" (Ricoeur 2004: 76).

Norman Bryson in Looking at the Overlooked (1991) considers that the inevitable sacrifice of reality in still life painting also induces a state of melancholy: "the reality of the still life as part of an actual world is sacrificed, and indeed that sacrifice is necessary if painting is to move from representation to presentation — to being staged, that is." (Bryson 1991: 81). The real world is lost to the still life in the process of becoming a world of its own. The viewer, however, never having experienced the reality sought out by the painter, experiences melancholy only as an affect of paint and painting.

Melancholic qualities in still life, as distinct from that which is represented, come about from the painter's modes of representation that in turn owe much to the technologies of paint 177 and techniques of painting available at a particular time. Most traditional and contemporary still life continues to be painted using oil paints though the range of application is anything but conventional. Of Glenn Brown's Burlesque mentioned earlier, the Tate web page states: “Through his use of colour, especially a putrid, festering hue of green, these subjects appear as though their life were draining away. One painter's image has been conflated with another's palette, transforming the cute ... into the deathly, and a serene, tempting still life of apples into a rotting mass." (Steiner and Gingera 2011). No object, nor its image, is melancholic in itself but instead depends for its effect on the palette, special qualities, viewpoint, mark-making and lighting employed. Together these produce an ambience, a mood, a feel and a context, to which the viewer responds. These approaches, combined with compositional arrangements that might involve tipping and tumbling, isolation or rigidity, microcosmic detail or suggestions of infinity, are the mechanisms of visual and sensory entrapment that can lead to a sense of reverie in the artist and viewer alike.

Play, like reverie, is a way of being open to tradition. As Gadamer states: "The movement of playing has no goal that brings it to an end; rather, it renews itself in constant repetition." (Gadamer 2006: 104). Memory enters the space of play, and the painter uses it and misuses it playfully. Play is purposeful but without an end in mind. 
Gadamer's idea of play is being "wholly with something else" in "a state of self forgetting" though not without self-knowledge (Gadamer 2006: 122). He writes that that "play draws [her] into its dominion and fills [her] with spirit" (Gadamer 2006: 109). James Elkins, the art historian, comes close to describing this fusion of memory, melancholy, reverie and play that is the preparation and process of painting at its most intense and open to potential: "An artist ... may not be sure of any categories - there is no clear difference between the artist and the half-formed work. Neither is in control, neither clearly "makes" the other. The experiment of art changes the experimenter and there is no hope of understanding what happens because there is no "I" that can absorb and control concepts—nothing has meaning apart from the substances themselves." (Elkins 1999: 166).

\section{Part II}

In part II I exemplify my thoughts on the playfully melancholic still life by considering the paintings of three contemporary painters of still life with whom I have worked on recent curatorial research projects.

\section{Alan Salisbury}

Alan Salisbury's Still Life with Sweets with Reference to Osias Beert's 'Three Dishes of Sweetmeats with Three Glasses' (2014) is an appropriation that acknowledges its traditional source in its title. Osias Beert the Elder was a prominent Flemish painter who worked in Antwerp at the turn of the seventeenth century. Like Beert's original painting, Salisbury's has an indeterminate horizon, a high and close viewpoint, inconsistent perspective, desaturated colours and a collection of sweetmeets though in Salisbury's paintings they are interspersed with contemporary popular confectionary-liquorice allsorts for example. Light has no source and space has no context. It is fathomless. Almost half of the painting is in darkness, actual or implied, a traditional feature of the melancholic still life from which it appropriates. The objects appear past their best, faded and dried out. The jelly snakes are depicted as entropic and floppy, in real life they stretch and split on being pulled, a sensation many of us might remember from childhood. The viewer is slightly lost in what appears, at first glance, to be a familiar enough traditional still life painting but is confused by its being playful pastiche. 


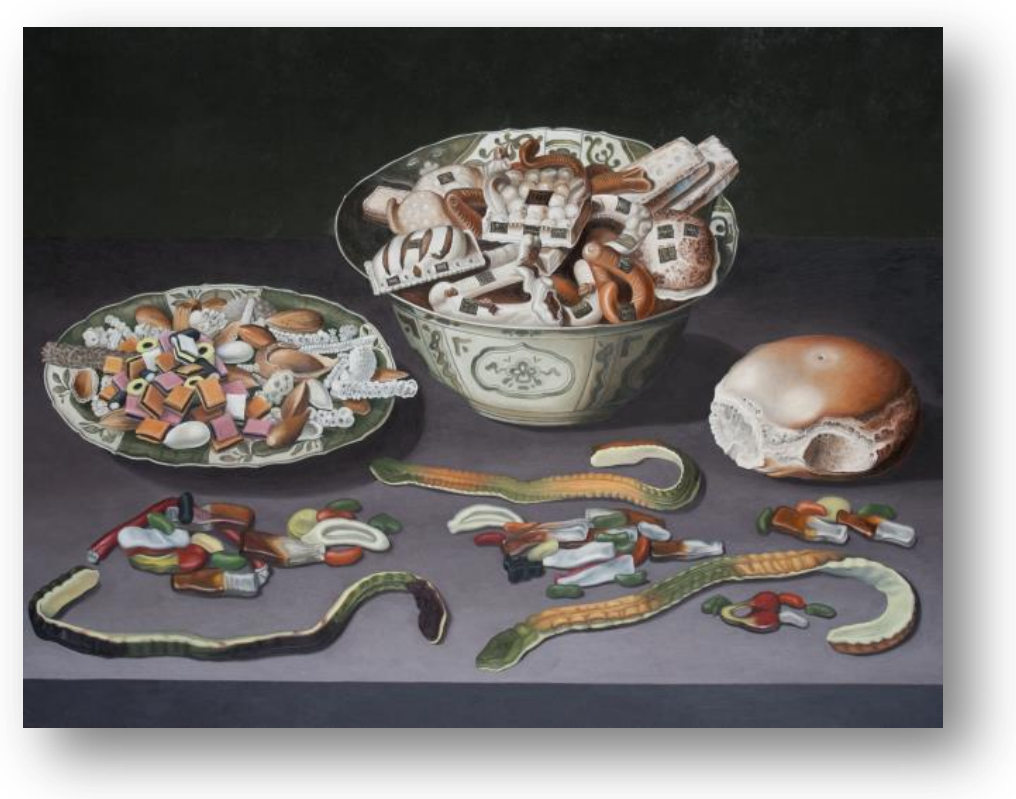

Alan Salisbury, Still Life with Sweets with Reference to Osias Beert's "Three Dishes of Sweetmeats with Three Glasses”, 2015, oil on board. Collection of the artist

Salisbury's Still life with Reference to 'Basket of Peaches with Quinces and Plums' by Louise Moillon, Circa 1641 from a Google Download (2014), seems less nostalgic and mischievous in its choice of subject matter. Yet here too Salisbury is playing with the irretrievability of the past and the melancholy inducing impossibility of the copy to live up to its origin. Salisbury's still life paintings are often a response to reproductions that he finds in books and websites. He plays with what are for him 'originals', having often never seen the actual painting. Photocopies and prints are made from reproductions that he grids up before beginning to play, a process that leads to adjustments and even re-composition. Yet, though his painting, like Beert's, is painted in oils, Salisbury's still lifes are possessed of a very different quality to their originals. The viewer is left unsure as to what can be remembered of an actual origin as Salisbury's 'copy' is so convincing-or even whether an original even existed. For Still life with Reference to 'Basket of Peaches ...', Salisbury worked from a particularly bad photocopy of an already low-resolution image. We need to recall here that a bowl of plums cannot be melancholic or nostalgic in itself. With the basket of plums of the original painting subjected to desaturation, indistinctness and flattening by over-exposure on the photocopier, Salisbury's painting here becomes hollow and moribund. Moillon's basket of fruit is left looking like the painter has wrung the life out of it-literally, and exquisitely. This painting is a melancholic ruin based on a false memory of an absent original. 


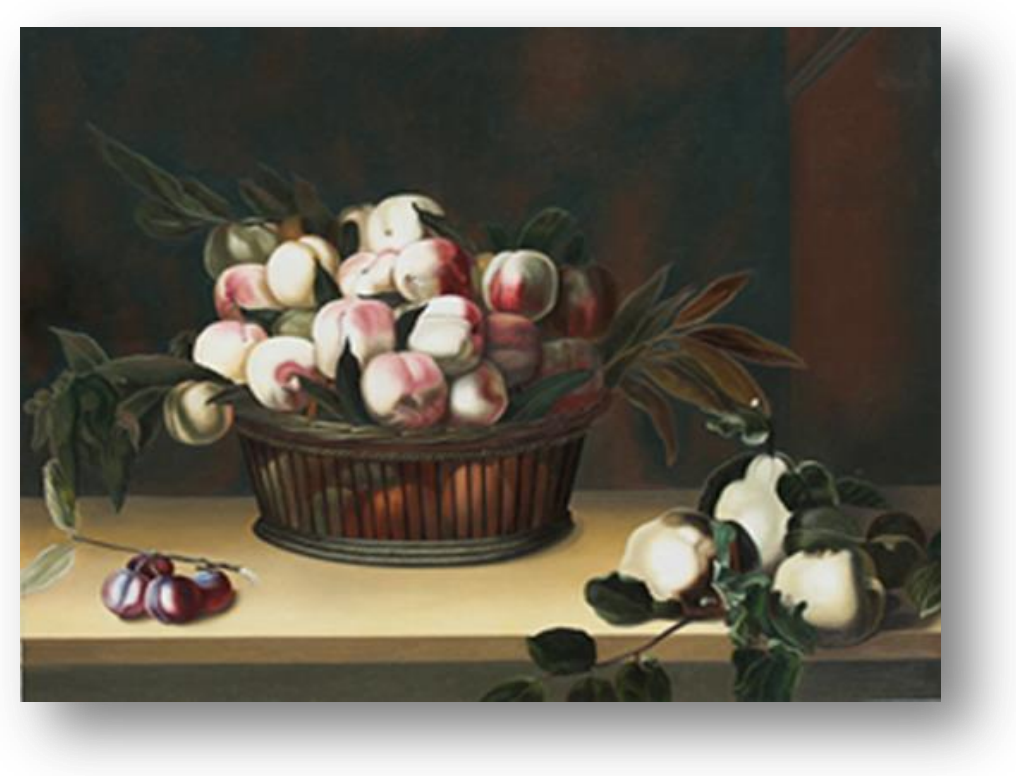

Alan Salisbury, Still life with Reference to 'Basket of Peaches with Quinces and Plums' by Louise Moillon, Circa 1641 from a Google Download, 2014, oil on board. Collection of the artist

\section{Emma Bennett}

Hollowed (Unhallowed) (2009) is a painting that invites introspection. It is painted on canvas using oil paints and various varnishes that have been made to craze and scumble when mixed. Bennett's painting is she says, "pastiche", but it is also a playful conversation with seventeenth and eighteenth century still life paintings. (Woodley 2014: 68). The painting is suggestive of a state of reverie in which past art is set free in the space and time of dreaming. In Hollowed (Unhallowed) Bennett paints a miniature collage of fruits directly sourced from her collection of reproductions of Willem van Aelst's paintings (1627-1683) and others. In her arrangement of the fruits, contrary to the original, they appear to be flying off or coming in to land on a transparent cloth shaped to reveal an absent surface beneath. There is no implication of gravity here, objects float, and it is not clear where, or when, or why they do so except in dream states. Above to the left, hang two dead birds, preserved or putrefied, sourced from game still lifes by the seventeenth century Dutch painter Jan Weenix the Younger (1640/9-1719) and Jean-Baptiste Oudry (1686 -1755). Displaced and rearranged, it is their fleeting resemblance to an original that is important here. Birds, fruit and cloth are bathed in fictional light, though not the light from a window as was still life's convention. Due to the absence of a light source very little shadow is cast except 
that found within the body of the motifs themselves. These are, in any case, inconsistent being appropriated from reproductions of different paintings. These peculiarities of painted light increase a sense of disjunction and ephemerality. Objects, weightless and fragile, cascade into a space of play and into a world of their own. Blackness, sometimes matt, sometimes lustrous, surrounds everything. But whether this darkness is night, an infinite void, a scenic backdrop or the black bile of melancholia it is impossible to say.

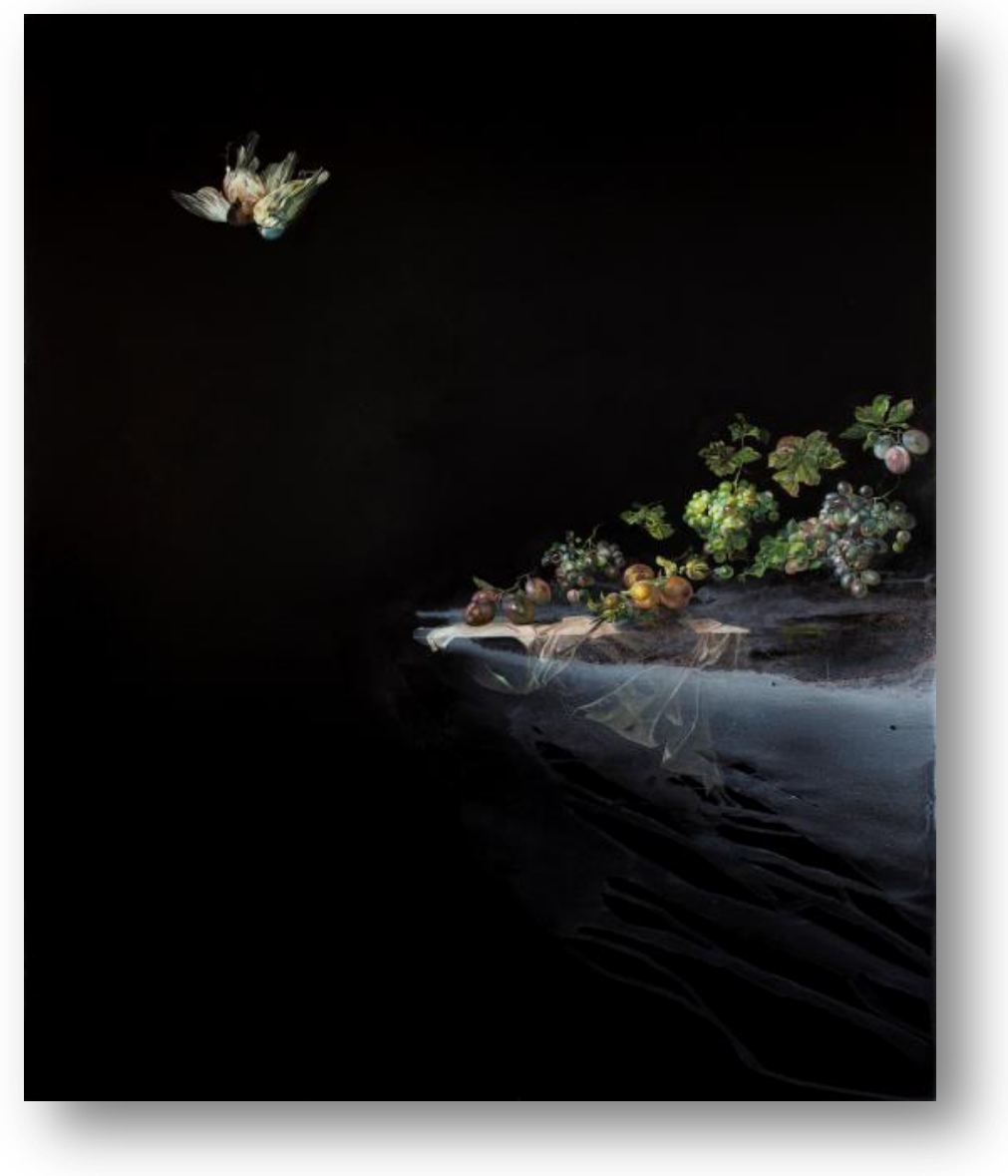

Emma Bennett, Hollowed (Unballowed), 2009, oil on canvas, $140 \times 110 \mathrm{~cm}$. Collection of the artist

At some point during the course of painting Bennett does something surprising-something that does not just subvert the tradition but also her own painting of it. It is a playful gamble that disrupts the reverie. She turns the painting on its side and administers a pour of pale translucent paint. This pour is a game changer, it is a playful intercession, and it has the power to change deep dark space into concrete flatness, and back. Such pours are a playful subversion of the tradition to which she is indebted. They are gestures that derive from her direct memory of pure abstraction. On physically being turned and re-turned, an abstract pour becomes transformed 
from material gesture to the evocation of something else. Bennett has made herself open to the address of traditional still life through its variety of reprographic technologies. She has responded to them by putting them to play, materially and visually to achieve a melancholic sense of drifting and floating.

In Tipping (towards love) (2014), Bennett makes use of the dynamic compositional developments that occurred in the seventeenth century pronk still lifes when luxurious still life became synonymous with tipping, tumbling, and over-hanging. In this painting Bennett appropriates from Willem Claesz. Heda's Still Life with Ham, Silver Jug and Roemer (1656). Again she sets these motifs of traditional still life against Baroque blackness, but less dramatically this time, more as if in limbo. Here, the cloth seems to reach out to a motif in which tumbling water beckons across space and time in the manner of pathetic fallacy. Foamy water and folded cloth are made to float in a state of melancholic longing such as when Bachelard writes: "The dream withdraws into this interior space and develops in the most paradoxical delight, in the most ineffable happiness." (Bachelard 2005: 91-92). In Bennett's correspondence with me she writes: "The intricacy of the historical still life paintings feels to me to reflect something of the intensity and complexity of human emotions, especially those associated with love and loss. ... I can include my own life experiences but keep the overall subject matter of the work universal.” (Woodley 2015: 23).

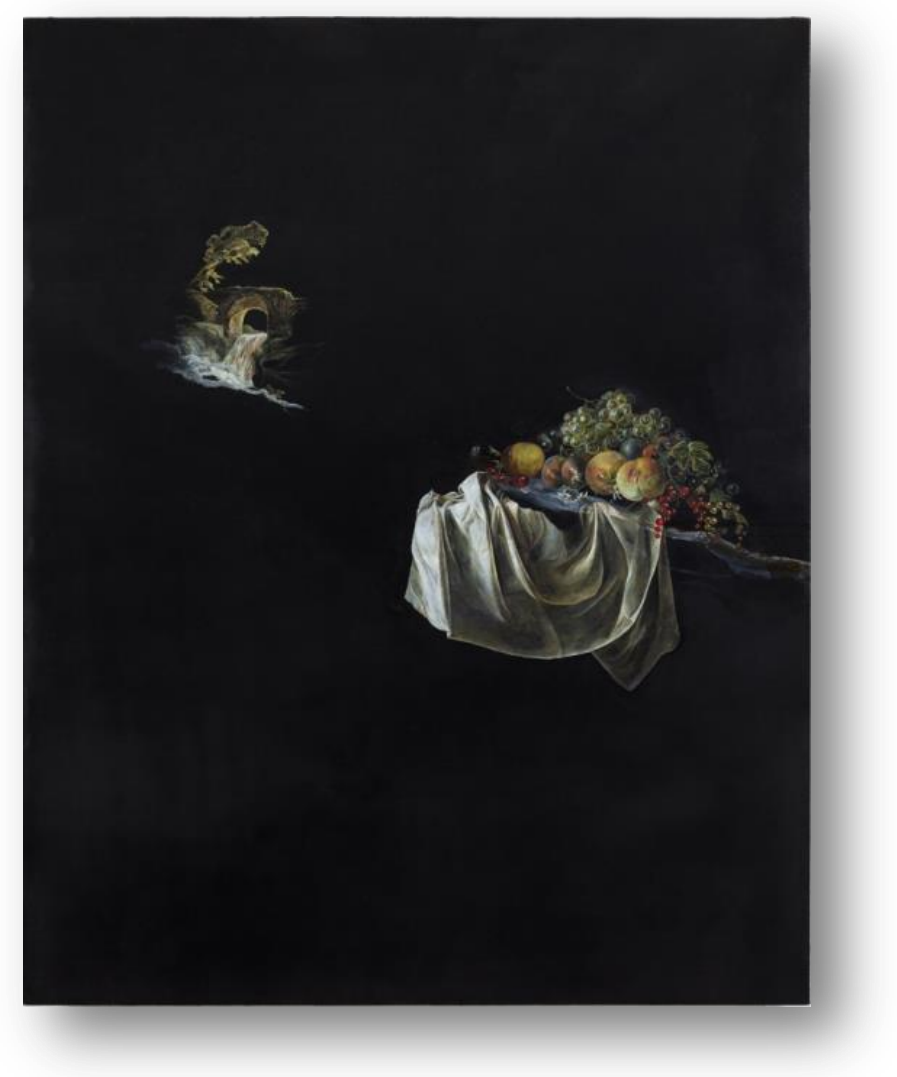

Emma Bennett, Tipping (towards love), oil on canvas $12 \times 91.5 \mathrm{~cm}$. Collection of the artist 


\section{G.L. Brierley}

Breirley's painted 'objects' are not appropriations. Instead, they are nameless things that have been realized out of the process of painting itself. These still lifes, as the artist refers to them, rely on the viewer's prior experience, memory, and powers of association, to tantalize and disturb. Neither abstract nor conceding obvious references to the still life tradition, her paintings nevertheless take as their context still life's formal conventions, that is, objects in relation to a surface in a space lit to reveal a world of their own.

“This 'lost thing' or memory of 'the thing before' has been at the route of my compulsion to make these paintings." (Woodley 2015: 29) So writes G.L. Brierley in our correspondence in July 2015. 'Lost objects' in Brierley's paintings evoke lost states, sensations, feelings and relationships. In her paintings, nameless objects exist beyond the reach of taxonomy or classification and are at once both abject and seductive. They serve as transitional or substitute objects with which personal associations and memories, their loss and lure, can be reclaimed and transformed by the painter.

In the painting Mylthruthe (2013) G.L.Brierley cuts, slices, embeds, stratifies, drags, marbles and scrapes her objects into and onto the painted panel. She writes that in this, and other paintings, she was "looking at the physicality of intimacy and the yearning for an unknowability or an unattainability of the thing" (Woodley 2015b). Her transitional or substitute objects are derived from ideas explored by the psychoanalyst, Donald Winnicott and the feminist writer, Julia Kristeva. (Woodley 2015a: 26). These painted 'objects' direct the viewer back to the trauma and melancholy of loss. However, Brierley's 'objects', for all the melancholic memories that inform them, are also playfully conceived as alchemical transmutations of matter and memory. Though painted, they are touchable and suggestible, physically seductive and saucy, yet strangely discomforting. 


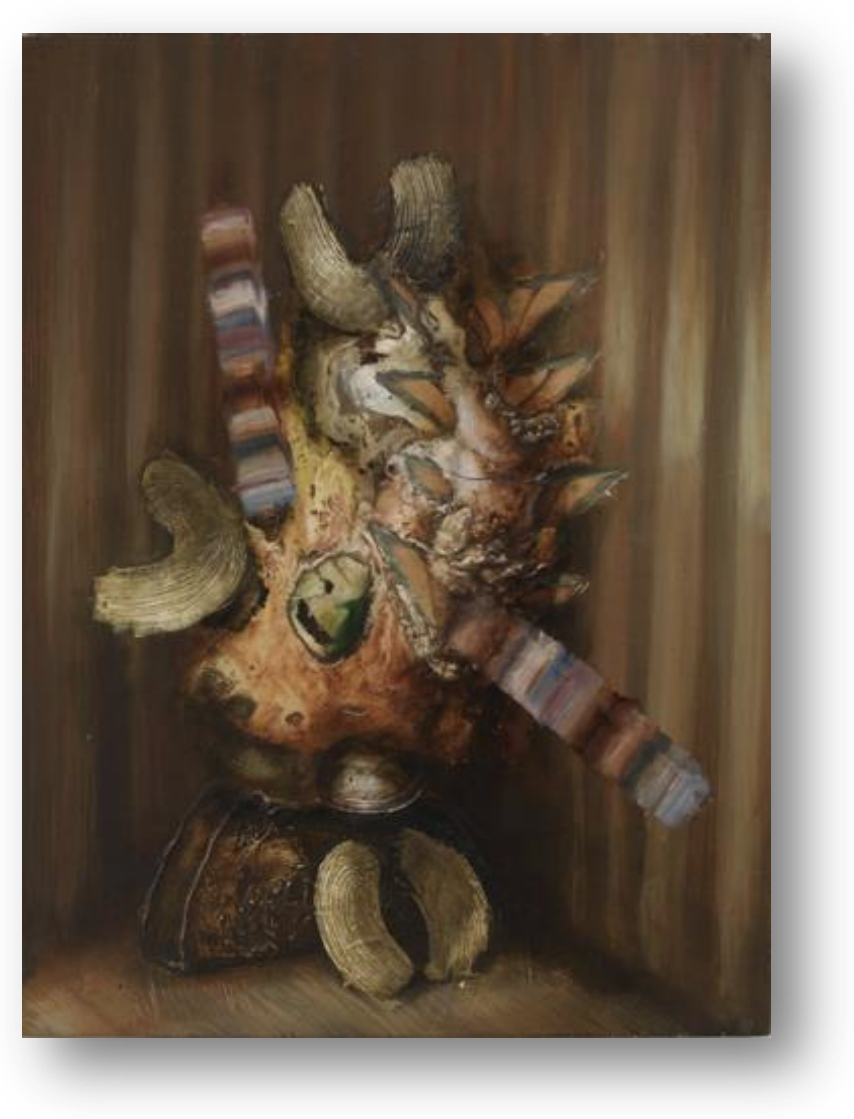

G.L. Brierley, Mylthrvthe, oil and inlay on panel, $30 \times 40 \mathrm{~cm}$. Collection of the artist

In Mylthrvthe the viewer sees no recognizable object represented there. This thing is nothing, yet it speaks to our loss of recognition, certainty, identity, place, and attachment-it is as if what we think we know is sliding away, and instead we are faced with the idiosyncratic logic of reverie and play. Yet the references could not be clearer. Brierley makes use of the tradition of melancholic representation-paint is wrinkled, viscous, dragged and suspended. Her 'objects are in penultimate states suggesting imminent decrepitude: they seek stability on a surface. To an art historically aware viewer, Brierley's still life paintings evoke the vanitas, not so much its literal warnings of the transience of life, but a contemporary correlation to the erosion of memory and life itself. Brierley's mother had dementia for the last fifteen years of her life, a condition in which memory, identity and dignity slip away.

The second of Breirley's paintings is Peecheap (2010). It is reminiscent of a birdbox, in which fledglings are kept safe and warm. But the hole is stretched, chapped, sagged and leaking, suggestive of bodily wear and tear. It is the embodiment of abjection bordering on the absurd, and is melancholic in the extreme. Surrounded by discarded nest fluff, or a riotous perm, there is 
also collapse, wrinkling, merging, sliding, frothiness and stretching-no horizon, only gloom. This still life, for it still seems to be that, feels as precarious and vertiginous as any seventeenth century pronk still life, but without the glitz. It is nothing that we can put a name to, yet it 'speaks' of loss, of decay, of fragility, of madness. Yet the painting itself is none of these things. Its impact is felt as affect, affect that is brought about by the playfully melancholic practice that is the contemporary painting of still life.

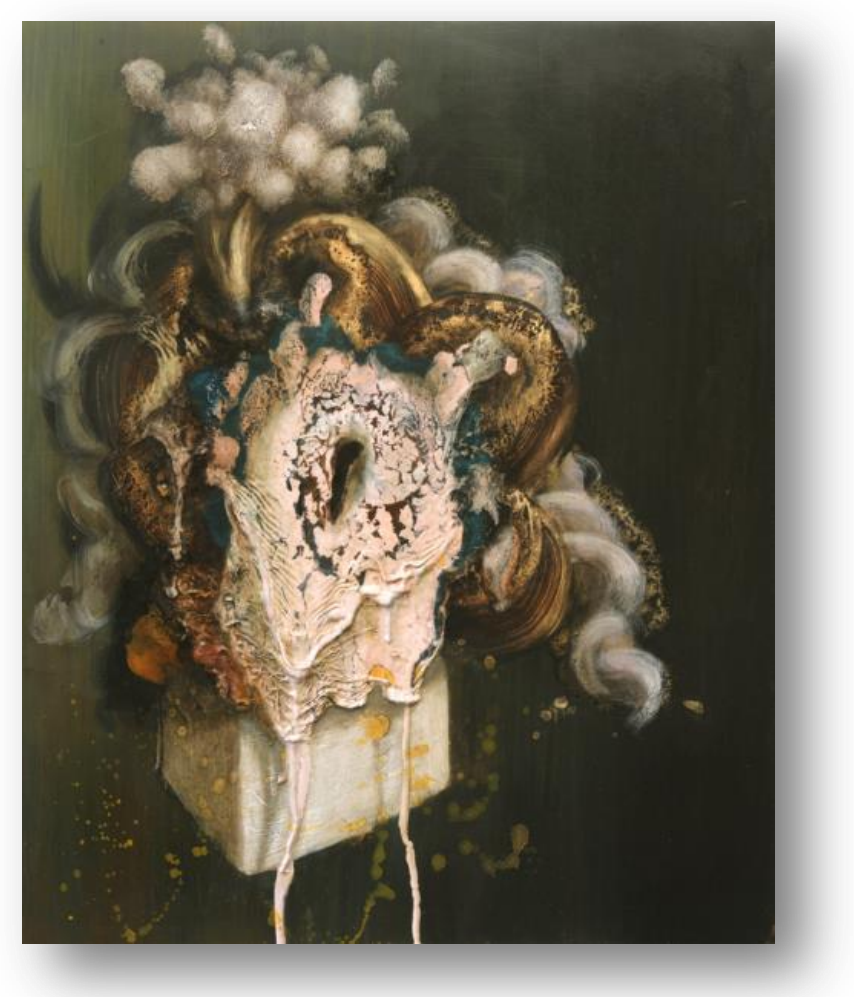

G.L. Brierley, Peecheap, oil on panel, 2013. Collection of the artist

\section{Conclusion}

Through my research it has become clear that the contemporary painting of still life is often a melancholic business, infused as it is with its memory of an origin and transformations such as that brought about by photography or cubism. Situating their practice in relation to traditional still life painting, contemporary painters of still life are keen to make the tradition their own. This 
is only possible through play, a transformational process that is staggering in the variety of possibilities it opens up yet always constrained both by its own time and the time of memory.

The case for contemporary painting of still life emerges now. In its endless variations, it presents its viewers with a meeting of horizons, that of history, memory and the present. Unrepeatable and personal memories and responses provide a seemingly infinite source of interpretive possibilities for the artist. But, while artists are both tantalized and constrained by tradition, they are also limited by their own horizon. "Every finite present has its limitation. ... The horizon is the range of vision that includes everything that can be seen from a particular vantage point.” states Gadamer. (Gadamer 2006: 301). Past and present are put into play in contemporary still life but the territory is bounded by the present-by what can be remembered of the past, and the melancholy for what is lost. The artist must explore and extend through purposeful play that which lies within the boundary of memory as it is encountered in her own time and place. The painting of still life, being a traditional genre, sets conditions for the creation of a world of its own, one that is in conversation with an historical past even as it circulates in the world from which it also retreats. "To understand [tradition] does not mean primarily to reason one's way back into the past, but to have a present involvement in what is said." (Gadamer 2006: 393). Bachelard, Gadamer's contemporary, goes further: "One must always maintain one's connection to the past and yet ceaselessly pull away from it.” (Bachelard 1988: 24).

\section{ACKNOWLEDGEMENTS}

All articles published in the issue are the revised texts based on lectures delivered at the $4^{\text {th }}$ International Interdisciplinary Memory Conference in Gdansk "Memory, Melancholy and Nostalgia” (17-18 Semptember, 2015). 
SUMMARY

\section{The (Playfully) Melancholic Still Life of Contemporary Painting}

This paper considers the ways in which contemporary painting of still life accepts the address of its tradition. Tradition is considered here as cultural memory reiterated and transformed over time. The means by which contemporary artists work with, and against, tradition are explored through ideas of reverie, play and material process. Melancholy is a characteristic of the genre of still life, one that crosses time, and is thus given particular attention in relation to traditional and contemporary still life. Whilst Part I is an exploration of the themes and issues described above, Part II (case studies) is an attempt to exemplify them through the work of three contemporary British painters: Alan Salisbury, Emma Bennett and G.L. Brierley of whom it can be said that they paint playfully melancholic paintings of still life.

KEYWORDS

Memory, melancholy, tradition, play, still life painting, contemporary painting

\section{BIBLIOGRAPHY}

Aristotle. 2001. 'On Memory and Reminiscence'. The Basic Works of Aristotle. McKeon, Richard ed. New York: Modern Library.

Bachelard Gaston. 2005. On Poetic Reverie and Imagination. Connecticut: Spring Publications.

Bachelard Gaston. 1988. Fragments of a Poetics of Fire. Dallas: Dallas Institute of Humanities and Culture.

Bracewell Michael. 2008. "Ged Quinn.” Online: https://frieze.com/article/ged-quinn. Accessed 30 October 2016.

Bryson Norman. 1991. Looking at the Overlooked. London: Reaktion.

Carter Rob and Carter Nick. 2012. MPC 'Transforming Still Life Painting.' Online: http://www.movingpicture.com/work/transforming-still-life-painting. Accessed 30 October 2016. 
Elkins James. 1999. What Painting Is. New York and London: Routledge.

Gadamer Hans-Georg. 2006. Truth and Method. London: Continuum.

Grootenboer Hanneke. 2006. The Rhetoric of Perspective: Realism and Illusionism in Seventeenth-Century Dutch Still Life Painting. Chicago: University of Chicago Press.

Levi-Strauss Claude. 1983. 'The Raw and the Cooked'. Mythologiques, Vol. 1, Chicago, University of Chicago Press, 1983.

Ricoeur Paul. 2004. Memory, History, Forgetting. Blamey Kathleen and Pellauer David. Chicago and London: University of Chicago Press.

Steiner Rochelle and Gingera Alison. 2011. "Glenn Brown: A Careful Concoction of 'Push and Pull." Online:

http://www.tate.org.uk/context-comment/articles/careful-concoction-push-and-pull. Accessed 20 October 2016.

Vroom N.R.A. 1999. A Modest Message as Intimated by the Painters of the Monochrome Banketje. Langehaven: Interbook International B.V.

Woodley Frances, ed. 2014. Still Life: All Coherence Gone?. Aberystwyth: Aberystwyth University.

Woodley Frances, ed. 2015a. Still Life: Ambiguous Practices. Aberystwyth: Aberystwyth University. ${ }^{1}$ Gadamer, Truth and Method (2006) 302.

Woodley Frances and Brierley G.L. 2015b. Conversation transcript.

\section{IMAGES}

Paintings not illustrated here are available on the internet. Artists' websites:

alansalisbury.com

www.glbrierley.com

www.emmabennett.info 